\title{
Kalosara di Kalangan Masyarakat Tolaki di Sulawesi Tenggara
}

\author{
Amiruddin, ${ }^{1}$ I Ketut Suardika, ${ }^{2}$ Anwar ${ }^{3}$ \\ 1. Jurusan Pendidikan Sejarah FIS Universitas Negeri Makassar Indonesia \\ 2. Jurusan Ilmu Pendidikan Universitas Haluoleo Indonesia \\ 3. Jurusan Pendidikan Sejarah FKIP Universitas Halu Oleo, Indonesia \\ E-mail: amiruddinunm@yahoo.co.id
}

\begin{abstract}
Pendidikan pada dasarnya berbasis sosial budaya berupa kegiatan pembelajaran yang didasarkan pada unsur-unsur budaya yang ada pada masyarakat setempat. Penelitian ini bertujuan: (1) untuk menganalisis fungsi kalosara dalam masyarakat Tolaki, (2) untuk mendeskripsikan fungsi kalosara sebagai media etnopedagogik dalam pengembangan karakter bangsa. Metode penelitian digunakan etnografi dengan pendekatan fenomenologis. Data dikumpulkan melalui studi pustaka, pengamatan, dan wawancara. Hasil analisis menunjukkan bahwa kalosara merupakan sumber dari segala adat-istiadat Orang Tolaki. Kalosara sebagai adat pokok dapat digolongkan ke dalam 5 cabang, yaitu: (1) sara wonua, yaitu adat pokok dalam pemerintahan; (2) sara mbedulu, yaitu adat pokok dalam hubungan kekeluargaan dan persatuan pada umumnya; (3) sara mbe'ombu, yaitu adat pokok dalam aktivitas agama dan kepercayaan; (4) sara mandarahia, yaitu adat pokok dalam pekerjaan yang berhubungan dengan keahlian dan keterampilan; dan (5) sara monda'u, mombopaho, mombakani, melambu, dumahu, meoti-oti, yaitu adat pokok dalam berladang, berkebun, beternak, berburu, dan menangkap ikan. Ada empat fungsi kalosara, yaitu: (1) ide, (2) focus dan pengintegrasian unsur-unsur kebudyaan, (3) pedoman hidup, serta (4) pemersatu. Fungsi kalosara sebagai media etnopedagogik merupakan praktek pendidikan berbasis kearifan lokal dalam berbagai ranah seperti pengobatan, seni bela diri, lingkungan hidup, pertanian, ekonomi, pemerintahan, dan sistem penanggalan. Melalui media kalosara, maka pengetahuan, nilai, dan keterampilan berbasis sosial budaya Tolaki dapat tumbuh dan berkembang di tengah-tengah masyarakat sebagai pengembangan karakter bangsa.
\end{abstract}

Kata kunci : Kalosara, Media etnopedagogi, Pengembangan karakter nasional

\section{Kalosara in Tolaki Society in South East Sulawesi}

Education is essentially a social and cultural events based learning activities that are based on cultural elements that exist in the local community. This study aims to: (1) to analyze the functions Tolaki kalosara in society, (2) to describe the function kalosara as etnopedagogik media in the development of the nation's character. Methods used ethnographic research with phenomenological approach. Data were collected through literature study, observation, and interviews. The analysis showed that kalosara is the source of all mores People Tolaki. Kalosara as principal customs can be classified into five branches, namely: (1) sara wonua, namely traditional staple in government; (2) sara mbedulu, namely traditional staple in family relations and unity in general; (3) sara mbe'ombu, the principal indigenous in religious activities and beliefs; (4) sara mandarahia, namely traditional staple in jobs related to their expertise and skills; and (5) sara monda'u, mombopaho, mombakani, melambu, dumahu, meoti-oti, ie indigenous staple in farming, gardening, farming, hunting, and fishing. Kalosara four functions, namely: (1) idea, (2) focus and integrating elements of the custom, (3) a rule of life, and (4) a unifier. Etnopedagogik media kalosara function as an educational practices based on local wisdom in various domains such as medicine, martial arts, environment, agriculture, economy, government, and the calendar system. Kalosara through the media, the knowledge, values, and skills-based socio-cultural Tolaki can grow and develop in the midst of society as a positive character development.

Keywords : Kalosara, Media Etnopedagogi, National Character Development 


\section{PENDAHULUAN}

Setiap suku bangsa berusaha memberikan pembelajaran kepada generasinya yang bertujuan untuk melestarikan budaya mereka, dan menyesuaikan diri dengan lingkungannya. Untuk dapat mempertahankan masyarakat sebagai kesatuan fungsional, harus selalu diadakan training bagi para anggota baru untuk dapat menempati posisi-posisi khusus dalam masyarakat. Para anggota masyarakat harus dibagi-bagi dalam berbagai kategori, dan setiap kategori harus dididik untuk melakukan berbagai macam hal. Masyarakat juga harus mengembangkan pola-pola tingkah-laku yang harus dilakukan individu dalam menghadapi situasi tertentu. Dengan adanya pola-pola semacam ini, maka muncul garis pegangan untuk memberikan training bagi individu. Dalam cultural continuum ada perwjudan baru yang ditambahkan, dan ada perwujudan lainnya yang dilepaskan (Linton 1984).

Pendidikan pada dasarnya berbasis sosial budaya berupa kegiatan pembelajaran yang didasarkan pada unsur-unsur budaya yang ada pada masyarakat setempat oleh Koentjaraningrat (1981) diidentifikasi seperti: sistem religi dan upacara keagamaan, sistem organsisasi kemasyarakatan, sistem pengetahuan, bahasa, kesenian, sistem mata pencaharian hidup, serta sistem teknologi dan peralatan.

Proses pembelajaran dalam bidang kebudayaan dikenal ada tiga istilah: discovery, invention, dan diffusion. Discovery adalah setiap penambahan pengetahun, invention adalah sebuah penggunaan baru daripada pengetahuan, diffusion adalah transfer unsur-unsur kebudayaan dari suatu masyarakat ke masyarakat lainnya.

Setiap kebudayaan merupakan sebuah formasi yang bagian-bagiannya saling menyesuaikan. Gejala saling menyesuaikan antara unsur-unsur kebudayaan ini disebut integration. Proses integrasi merupakan perkembangan progresif dalam rangka mewujudkan persesuaian yang sempurna antara berbagai unsur yang secara bersama mewujudkan budaya sempurna (total culture). Linton (1984) memberi contoh terjadinya perubahan dalam kehidupan masyarakat Suku Tanala di Madagaskar sebagai akibat masuknya sistem teknologi bersawah, yang sebelumnya mereka hanya mengenal sistem penanaman padi ladang.
Kebudayaan merupakan suatu proses belajar. Misalnya dalam kesenian, manusia terus-menerus mencari bentuk-bentuk ekspresi baru. Dalam bidang religi manusia berusaha untuk menanggapi kekuasaan ilahi dengan simbol bahasa, tanda-tanda dan perbuatan yang terus menerus diperbaharuinya. Meskipun demikian melalui kebudayaan tidak selalu menghasilkan yang positif. Melalui trial and error, kita menjadi bijaksana, namun dapat juga terjadi sebaliknya, bahwa manusia melalui kekeliruan dan kesalahan menjadi makin bodoh, bahkan sukses dan kesejahteraan tidak selalu menambah pengetahuan. Kebudayaan sebagai proses belajar tidak menjamin kemajuan dan perbaikan yang sejati. Namun sebagai bangsa atau individu yang baik diharapkan menjadikan kebudayaan sebagai proses belajar untuk menjadi lebih baik dari kehidupan sebelumnya (Peursen, 1988).

Proses pembelajaran keterampilan dan nilai merupakan proses transmisi kebudayaan. Dalam transmisi menurut Fortes terdapat tiga unsur utama, yaitu: (1) unsur-unsur yang ditransmisi, (2) proses transmisi, dan (3) cara transmisi (Tilaar, 1999). Unsur-unsur budaya yang ditransmisi adalah nilainilai budaya (adat-istiadat, pandangan mengenai hidup), kebiasaan sosial dalam pergaulan, sikap dan peranan, tata makanan untuk dapat bertahan hidup.

Proses transmisi meliputi proses: imitasi, identifikasi, dan sosialisasi (Tilaar, 1999). Imitasi adalah meniru tingkah-laku dari sekitar, mulai dari lingkungan keluarga kemudian meluas terhadap masyarakat lokal. Proses identifikasi berjalan sepanjang hayat sesuai dengan tingkat kemampuan manusia itu sendiri. Selanjutnya unsur-unsur budaya itu harus disosialisasikan yaitu diwujudkan dalam kehidupan nyata sehingga mendapat pengakuan sosial. Proses transmisi dilakukan dalam dua bentuk yaitu peran serta dan bimbingan. Cara transmisi melalui peran serta antara lain dengan perbandingan atau ikutserta dalam kegiatan seharihari di lingkungan masyarakat. Bentuk bimbingan dapat berupa instruksi, persuasi, dan ransangan.

Pengetahuan, nilai, dan keterampilan berbasis sosial budaya Tolaki telah tumbuh di tengah-tengah masyarakat. Pengetahuan, nilai, dan keterampilan tradisional yang telah dimiliki oleh masyarakat Tolaki, tidak semuanya harus ditinggalkan, tetapi sebagian diantaranya dapat dikembangkan 
berdasarkan pertimbangan tertentu, sebagaimana tersimpul dari empat fungsi kalosara, yaitu: (1) ide (2) focus dan pengintegrasian unsur-unsur kebudyaan, (3) pedoman hidup serta (4) pemersatu (Tarimana, 1989).

Etnopedagogi adalah praktek pendidikan berbasis kearifan lokal dalam berbagai ranah seperti pengobatan, seni bela diri, lingkungan hidup, pertanian, ekonomi, pemerintahan, sistem penanggalan, dan lain-lain. Etnopedagogi memandang pengetahuan atau kearifan lokal sebagai sumber inovasi dan keterampilan yang dapat diberdayakan demi kesejahteraan masyarakat. Kearifan lokal mengandung koleksi fakta, konsep kepercayaan, persepsi masyarakat ihwal dunia sekitar, menyelesaikan masalah, dan memvalidasi informasi. Kearifan lokal merupakan rangkaian pengetahuan dihasilkan, disimpan, diterapkan, dikelola, dan diwariskan (Surya, 20113). Ada beberapa ciri kearifan lokal, yaitu: (1) berdasarkan pengalaman, (2) teruji setelah digunakan berabad-abad, (3) dapat diadaptasi dengan kultur ini, (4) padu padan dalam praktek keseharian masyarakat dan lembaga, (5) lazim dilakukan oleh individu atau masyarakat secara keseluruhan, (6) bersifat dinamis dan terus berubah, dan (7) sangat terkait dengan sistem kepercayaan (Alwasilah, 2008).

Etnopedagogi adalah praktik pendidikan berbasis pengetahuan lokal dalam berbagai aspek kehidupan. Ini akan tumbuh menjadi ethnophilosophy, ethnopsychology, ethnomusicology, ethnopolitics, dan lain-lain. Etnopedagogi memandang pengetahuan atau kearifan lokal (indigenous knowledge, local wisdom) sebagai sumber inovasi dan keterampilan yang dapat diberdayakan untuk kesejahteraan masyarakat. Menurut Alwasilah (2008) ada beberapa karakteristik dari kearifan lokal: (1) berdasarkan pengalaman, (2) diuji setelah digunakanselama berabad-abad, (3) dapat disesuaikan dengan budaya sekarang, (4) terpadu di setiap hari praktik dan lembaga-lembaga masyarakat, (5) umumnya dilakukan oleh individu atau masyarakat secara keseluruhan, (6) adalah dinamis dan selalu berubah, dan (7) sangat terkait dengan sistem kepercayaan. Pemberdayaan melalui adaptasi pengetahuan lokal, termasuk reinterpretasinilainilai yang terkandung dalam sejumlah peribahasa, dengan kondisi kontemporer adalah strategi cerdas untuk memecahkan masalah sosial karena dalam banyak hal masalah-masalah sosial yang berasal dari isu-isu lokal juga.

Pemimpin lebih mudah untuk mengarahkan anak buahnya dengan norma-norma yang umum di masyarakat. Kearifan lokal bisa menjadi kendaraan yang Sinergi tujuan modernisasi dengan pelestarian keunggulan lokal. Bagi Masyarakat Sulawesi Tenggara, khususnya Masyarakat Tolaki yang memiliki kearifan lokal dalam bentuk kalosara yang berfungsi sebagai media dalam etnopedagogi.

Etnopedagogi didefinisikan sebagai model pembelajaran lintas-budaya. Guru mampu mengajar di setting budaya yang setempat yang mungkin berbeda. Siswa adalah pembelajar lintas budaya. Siswa mana pun di dunia biasanya menunjukkan ada pola pikir serupa. Hal ini dapat diartikan bahwa untuk memberikan pemahaman baru harus disesuaikan dengan nilai-nilai budaya yang berlaku di lingkungan setempat. Hal baru dapat dengan mudah diterima jika mengandung nilainilai yang sejalan dengan nilai-nilai lokal. Pendidikan juga menyediakan nilainilai universal yang harus ada di setiap nilai order di dunia. Sebaliknya, nilai-nilai lokal yang sangat baik juga bisa diangkat dan disosialisasikanke dalam dunia yang lebih luas. Pendidikan melalui pendekatan etnopedagogi, melihat pengetahuan lokal sebagai sumber inovasi dan keterampilan yang dapat diberdayakan (Surya, 2011).

Etnopedagogi terkait erat dengan pendidikan multikultural. Pendidikan multikultural memuat perangkat kepercayaan yang memandang penting kearifan lokal dan keberagaman yang dimiliki komunitas etnis untuk membentuk gaya hidup, pengalaman sosial, identitas pribadi, dan kelompok sosial maupun negara. Ketika etnopedagogi memandang pengetahuan atau kearifan lokal sebagai sumber inovasi dan keterampilan, dilanjutkan dengan pendidikan multicultural yang memberdayakan inovasi dan keterampilan itu agar dapat menyumbangkan masukan positif bagi kelompok sosial lain dan budaya nasional.

Beberapaka penelitian terkait dengan penelitian ini, seperti Hasil penelitian Taena (2016) menyimpulkan bahwa pendidikan karakter terintegrasi dalam pendidikan seni budaya yang berbasis budaya lokal sangat penting diterapkan di sekolah. Makna yang 
muncul dalam tekas kabanti kantola mengandung nasehat, kritik membangun, membingbing dan mengarahkan karakter masyarakat untuk menjadi baik dan positif berdasarkan sudut pandang masyarakatnya.

Hasil penelitian Suardika (2016) menyimpulkan bahwa fungsi pendidikan iko-iko dalam Komunitas Bajo bahwa terdapat sejumlah pengetahuan, nilai dan sikap yang disampaikan oleh penutur kepada pendengar berupa nilai kejujuran, kedisiplinan, benar salah, baik buruk, anjuran rajin bekerja dan berbuat sesuatu yang bermanfaat bagi diri dan orang lain.

Berdasarkan pemikiran hasil penelitian tersebut, maka penelitian ini dirancang dengan tujuan : (1) untuk menganalisis fungsi kalosara dalam masyarakat Tolaki, (2) untuk mendeskripsikan fungsi kalosara sebagai media etnopedagogik dalam pengembangan karakter bangsa. Metode penelitian digunakan etnografi dengan pendekatan fenomenologis. Data dikumpulkan melalui studi pustaka, pengamatan, dan wawancara. Analisis data dilakukan secara deskriptif kualitatif.

\section{PEMBAHASAN}

\section{Konsep dan Fungsi Kalosara dalam Masyarakat Tolaki}

Secara harfiah, kalo adalah suatu benda yang berbentuk lingkaran, cara-cara mengikat yang melingkar, dan pertemuan atau kegiatan bersama dengan pelaku membentuk lingkaran. Sebagai benda lingkaran, kalo dibuat dari rotan, dan ada juga yang terbuat dari bahan lainnya, seperti emas, besi, perak, benang, kain putih, akar, daun pandan, bambu dan sebagainya (Tarimana, 1993).

Kalosara terdiri atas 3 bagian, yaitu: (1) kalo, berupa lilitan tiga rotan yang melingkar, (2) kain putih sebagai mengalas, dan (3) siwoleuwa, yaitu anyaman dari daun palem berbentuk persegi empat (Misran Safar, wawancara 17 Juni 2016). Ketiga wadah ini jika berdiri sendiri tidak memiliki arti dan fungsi adat, kecuali ketiganya menyatu dalam suatu tatanan dengan struktur sebagai wadah pengalas paling bawah berupa simoleuwa, kemudian dilapisi di atasnya dengan kain putih, dan di atas kedua wadah ini diletakkan kalo.

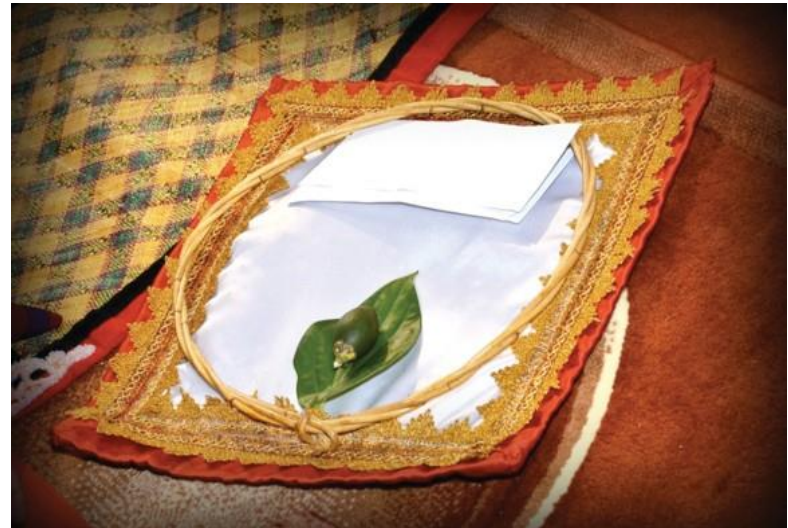

Gambar 1. Tampak Sebuah Kalosara (Wadah: kalo, kain kaci, dan Siwole)

Berdasarkan bahan pembuatan dan pemanfatannya, maka kalo banyak jenisnya, tetapi dalam tulisan ini hanya membahas kalosara yaitu kalo yang digunakan sebagai alat upacara perkawinan adat, upacara pelantikan raja, upacara penyambutan tamu penting, upacara perdamaian atas suatu sengketa, alat bagi sejumlah tokoh untuk menyampaikan sesuatu saran/pendapat kepada pejabat, alat untuk menyampaikan undangan pesta keluarga. Kalosara ini dalam pemanfaatannya dilengkapi dengan wadah anyaman dari tangkai daun pelem, dan kain putih sebagai alas.

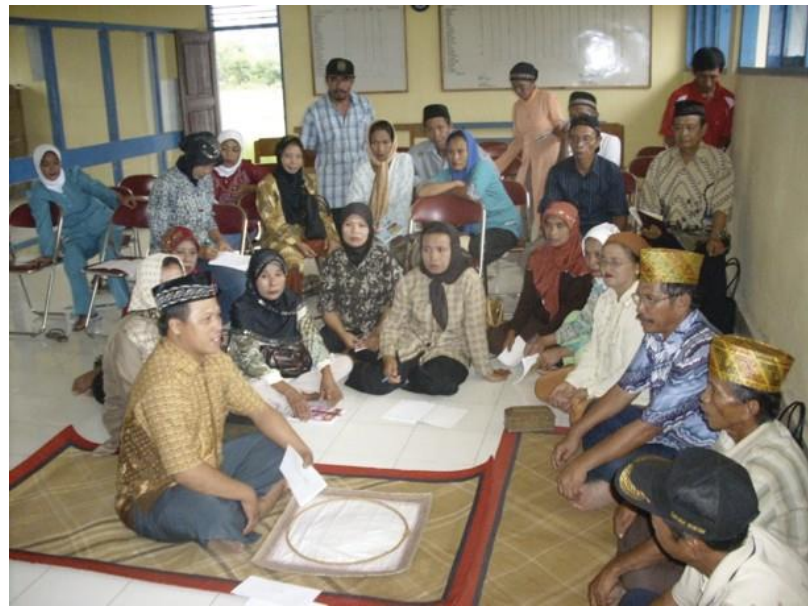

Gambar 2. Tampak Seorang Tolea Menghadapi Sebuah Kalosara (Wadah: kalo, kain kaci, dan Siwole)

Peristiwa di mana seseorang, yang karena merasa sangat malu atas pelakuan seseorang lainnya yang tidak sopan terhadapnya di depan umum, melakukan reaksi keras berupa ancaman penganiayaan terhadap orang yang memperlakukannya demikian untuk membela harga dirinya. Dalam situasi yang demikian muncullah pihak ketiga menampilkan 
kalosara di antara keduanya yang sedang ancammengancam satu sama lain. Tanpa komentar dari ketiganya, peristiwa ancam-mengancam tersebut berhenti secara otomatis di mana keduanya akan saling maaf-memaafkan karena bagi mereka kalosara identik dengan perkataan: "jangan, mohon maaf, ampun, engkau, dia, dan aku, serta kita sekalian adalah satu kesatuan, satu di dalam tiga, dan tiga di dalam satu." Menganiaya dia berarti menganiaya diri sendiri, dan menganiaya aku serta kita sekaliannya. Dengan tampilnya kalosara itu dalam suasana demikian maka damailah keduanya. Bila ternyata salah satu dari keduanya atau keduaduanya menolak adanya kalosara dalam peristiwa itu, maka ia telah dipandang terkutuk dan akibatnya mereka harus dikeluarkan dari warga Orang Tolaki atau menghukum mereka dengan ketentuan adat yang berlaku.

Selanjutnya,bagaimana hubungan antara asas mata pencaharian Orang Tolaki dengan kalosara? Hubungan itu tampak pada tiga kenyataan yang digambarkan di bawah ini sebagai berikut: Kenyataan bahwa kalosara selalu digunakan sebagai tanda pemilikan, dan tanda larangan, penjaga tanaman terhadap gangguan hama dan gangguan orang lain. Selain itu kalosara secara simbolik adalah ganti diri dari pemilik tanah dan tanaman di atasnya.

Selanjutnya, bagaimana hubungan antara asas sistem teknologi tradisional Orang Tolaki dengan kalosara? Hubungan itu nampak pada kenyataankenyataan yang digambarkan di bawah ini. Kenyataan bahwa pada umumnya alat-peralatan memerlukan pengikat rotan, yang teknik mengikatnya adalah selalu identik dengan model ikatan kalosara yang melilit, melingkar, dan membulat. Semua hulu dari alat-alat produktif dan senjata selalu diikat dengan teknik khusus yang disebut holungu (ikatan melingkar yang dianyam); demikian pula semua wadah anyaman diperkuat bobotnya dengan lingkaran rotan yang dipilin, dan hampir semua dari model perhiasan identik dengan model kalo yang melingkar, dan membulat.

Pergeseran nilai dan peranan kalosara masa kini. Hubungan sistem kekerabatan dan organisasi sosial dengan kalo, perlu memberi uraian mengenai sikap orang Tolaki masa kini terhadap kalo. Untuk mengetahui sikap orang Tolaki masa kini terhadap kalo, yaitu: (1) tampak pada kesenian yaitu dalam hal bentuk, (2) terletak pada makna-makna simbolik yang terkandung di dalamnya (Muslimin Su"ud, wawancara, 24 Juni 2016).

Bentuk-bentuk disain dalam pola segi empat, lingkaran, ikat, dan pola gambar tumbuhan pakis, pola kepala orang; bentuk-bentuk rias tubuh dalam bulatan, bentuk-bentuk demikian berupa benda perhiasan dalam pola lingkaran; bentuk-bentuk alat-alat bunyi dalam pola bulatan; bentuk-bentuk teknik menari dalam pola lingkaran dan pola gerakan horisontal-vertikal yang membentuk pola segi empat; semua menunjukkan corak yang sama dengan bentuk pola kalo, yakni: lingkaran, ikatan, dan segi empat.

Konsep kalo dalam kebudayaan Tolaki sangat luas ruang lingkup dan maknanya. Kalo secara umum meliputi o sara (adat istiadat), khususnya sara owoseno Tolaki atau sara mbu'uno Tolaki, yaitu adat pokok (Instrumen utama), yang merupakan sumber dari segala adat-istiadat Orang Tolaki yang berlaku dalam semua aspek kehidupan mereka. Kalo sebagai adat pokok dapat digolongkan ke dalam 5 cabang, yaitu: (1) sara wonua, yaitu adat pokok dalam pemerintahan; (2) sara mbedulu, yaitu adat pokok dalam hubungan kekeluargaan dan persatuan pada umumnya; (3) sara mbe'ombu, yaitu adat pokok dalam aktivitas agama dan kepercayaan; (4) sara mandarahia, yaitu adat pokok dalam pekerjaan yang berhubungan dengan keahlian dan keterampilan; dan (5) sara monda'u, mombopaho, mombakani, melambu, dumahu, meoti-oti, yaitu adat pokok dalam berladang, berkebun, beternak, berburu, dan menangkap ikan (Tarimana, 1993; Idam 2012).

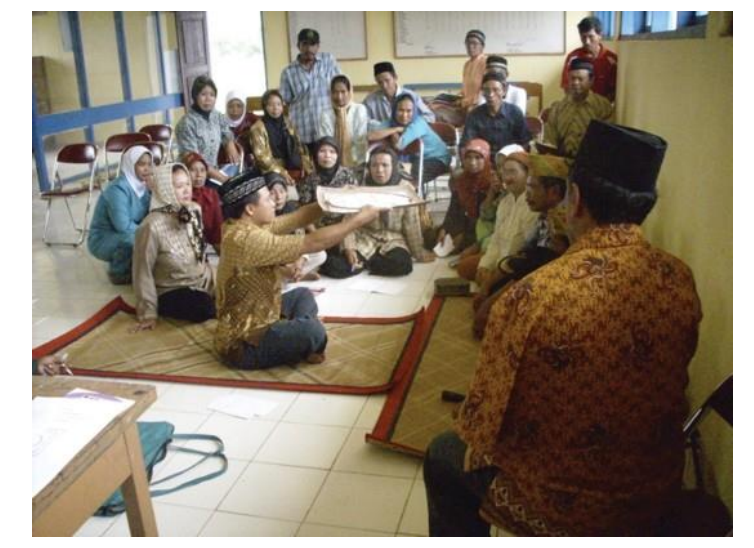

Gambar 3. Tampak Seorang Tolea Sedang Memperagakan Pemanfaatan Kalosara (Mengangakat Sebuah Kalosara) 
Menurut Tarimana (1993) kalosara bagi masyarakat Tolaki merupakan sesuatu yang dapat mengintegrasikan unsur-unsur yang ada dalam kebudayaan Tolaki, memiliki 4 fungsi:

1) Kalo sebagai ide dalam kebudayaan dan sebagai kenyataan dalam kehidupan orang Tolaki. Kalo pada tingkat nilai budaya adalah sistem nilai yang berfungsi mewujudkan ide-ide yang mengkonsepsikan hal yang paling bernilai bagi Masyarakat Tolaki, adalah apa yang disebut medulu mepoko'aso (persatuan dan kesatuan), ate pute penao moroha (kesucian dan keadilan), morini mbu'umbundi monapa mbu'undawaro (kemakmuran dan kesejahteraan). Ide ini dinyatakan melalui penggunaan kalo dalam setiap upacara perkawinan, kematian, upacara tanam dan potong padi atau pun pada setiap upacara penyambutan tamu. Selain itu, ide ini juga diwujudkan dalam kehidupan sehari-hari, misalnya dalam apa yang disebut mete' alo-alo (bantu-membantu) dan lainlain. Akhirnya ide kesejahteraan misalnya diwujudkan dalam apa yang disebut mombekapona-pona'ako (saling hormatmenghormati), mombekamei-meiri'ako (saling kasih-mengasihi), ndundu karandu (suasana ketenangan batin yang diliputi dengan alunan bunyi gong yang merdu di tengah malam), dan tumotapa rarai (suasana kegembiraan yang diliputi dengan suara hura-hura, tawa, dan tepuk tangan yang meriah).

2) Kalo sebagai fokus dan pengintegrasian unsurunsur kebudayaan Tolaki. Kalo bagi Masyarakat Tolaki, bukan hanya sekedar simbol, tetapi juga fokus dalam pengintegrasian unsur-unsur kebudayaan Tolaki, yakni: (1) dalam bahasa, sebagai lambang komunikasi; (2) dalam sistem ekonomi tradisional, sebagai penjaga tanaman, dan sebagai asas distribusi barang-baranag ekonomi; (3) sistem teknologi tradisional, sebagai model mengikat dan bentuk alat-alat; (4) organisasi sosial, sebagai asas politik dan pemerintahan; (5) sistem pengetahuan, dalam hubungannya dengan alam semesta; (5) sistem kepercayaan, dalam hubungan struktur alam dunia; dan (6) sistem kesenian, dalam bubungan bentuk rias, dan teknik menari.

3) Kalo sebagai pedoman hidup untuk terciptanya ketertiban sosial dan moral dalam kehidupan Masyarakat Tolaki. Untuk terciptanya ketertiban sosial dan moral dalam kehidupan masyarakat, penggunaan Kalo sebagai pedoman hidup untuk terciptanya ketertiban sosial dan moral tampak dalam usaha memulihkan suasana kelaparan karena panen gagal atau karena bencana alam atau peristiwa lainnya. Masyarakat Tolaki menganggap bahwa timbulnya suasana yang tidak baik akibat dari manusia yang telah melanggar adat ataupun ajaran agama, atau telah melanggar ajaran Kalo sebagai instrumen adat utama mereka. Untuk memulihkan suasana semacam ini, maka diadakanlah upacara yang disebut mosehe wonua (upacara pembersihan negeri) yang diikuti oleh segenap besar warga masyarakat.

4) Kalo sebagai pemersatu dan solusi terhadap pertentangan-pertentangan sosial budaya dalam kehidupan masyarakat Tolaki.

\section{Hubungan Kalosara Dengan Kesenian}

Hubungan pertama yang tampak di antara kesenian dengan kalosara adalah dalam bentuk. Hubungan kedua terletak pada makna-makna simbolik yang terkandung di dalamnya. Bentuk-bentuk disain dalam pola segi empat, lingkaran, ikat, dan pola gambar tumbuhan pakis, pola kepala orang, bentuk-bentuk rias tubuh dalam pola buatan, demikian bentuk benda-benda perhiasan dalam pola lingkaran; bentuk alat-alat bunyi dalam pola buatan; bentuk teknik menari dalam pola lingkaran dan pola gerakan horizontal-vertikal yang membentuk pola segi empat; semuanya menunjukkan corak yang sama dengan bentuk pola kalosara, yakni: lingkaran, ikatan, dan segi empat.

Dimensi diadik dalam pola garis-garis dan segi empat pada disain, pola dua dan empat baris per bait pada puisi, pola gerakan dua-tiga (ke kiri dua langkah, ke kanan tiga langkah) dan membentuk lingkaran, dan pola tiga bergandengan: lakiperempuan laki, atau perempuan-laki-perempuan pada tarian, ide kesatuan dan persatuan yang tercermin dalam pola bulatan pada rias tubuh dan pola lingkaran pada perhiasan; semuanya menunjukkan ide atau asas yang sama pada kalosara, yaitu: asas dualisme, asas triparti, dan asas kesatuan.

Pencerminan klasifikasi dua, klasifikasi tiga, dan klasifikasi lima pada kalosara. Tiga macam klasifikasi ini dalam makna simbolik dari kalosara. Klasifikasi dua tercermin di dalam unsur dua ujung 
rotan yang membentuk kalosara. Menurut konsepsi masyarakat Tolaki, dua ujung rotan itu adalah simbol dari laki dan perempuan, dan semua unsur dua yang saling bertentangan atau yang dapat dipertentangkan, misalnya: jasmani dan rokhani, manusia dan hewan, manusia dan tumbuhan, dunia nyata dan dunia gaib, dan seterusnya.

Makna simbolik dari dua ujung rotan yang menunjukkan klasifikasi dua tampak ketika upacara peminangan. Dalam ruang upacara duduk kelompok peserta upacara dari pihak laki-laki di satu sisi ruangan, dan peserta upacara dari perempuan di sisi yang lain secara berhadap-hadapan. Kedua pihak itu saling bersaingan dalam hal menetapkan jenis dan jumlah mas kawin dan biaya perkawinan yang akan datang. Pihak perempuan meminta banyak dan pihak laki-laki minta sedikit yang satu minta turun, yang lain minta teta tidak turun dari jumlah yang telah dimintanya. Gejala lain di mana dua ujung rotan itu tampak sebagai klasifikasi dua kanan adalah keluarga pengantin perempuan pihak ayah, yang duduk pada posisi kiri adalah keluarga pengantin laki-laki pihak ibu, yang duduk pada posisi muka-belakang adalah masing-masing keluarga dari masing-masing keluarga pengantin lakilaki dari pihak ayah, dan keluarga pengantin perempuan dari pihak ibu. Sedangkan yang duduk di tengah di mana kalosara ditempatkan adalah dua juru bicara dari masing-masing keluarga pengantin dan dua pasang suami-istri, ialah paman-bibi dari masing-masing pengantin, yang duduk saling berhadapan. Demikian juga peserta upacara, misalnya dalam upacara pergantian tahun pertanian, biasanya diatur demikian rupa, sehingga mereka yang mengambil tempat di bagian timur lapangan adalah penduduk yang berasal dari wilayah timur desa, yang mengambil tempat di bagian barat lapangan berasal dari wilayah barat desa, yang mengambil tempat di bagian utara lapangan berasal dari wilayah utara desa, yang mengambil tempat di bagian selatan lapangan berasal dari wilayah selatan desa, sedangkan mereka duduk di tengah lapangan upacara di mana kalosara dan alat-alat upacara serta bangunan panggung berada adalah dukun upacara yang dikelilingi oleh para tokoh adat dan tokoh masyarakat setempat (Su'ud, 2012).

Kenyataan-kenyataan tersebut di atas menunjukkan bahwa kalosara dalam upacara merupakan simbol dari unsur-unsur klasifikasi lima.
Kalosara dalam fungsinya sebagai pengikat rumah, juga melambangkan unsur-unsur klasifikasi lima, berdasarkan asosiasi Masyarakat Tolaki yang mengidentifikasi kalosara dengan tiang tengan rumah, di mana tiang tengah rumah berfungsi sebagai pusat tata ruang rumah yang mencerminkan unsur-unsur ruang rumah, yaitu: sisi kanan-kirimuka-belakang-pusat rumah.

\section{Implementasi Kalosara Sebagai Media Etnope- dagogi Dalam Kehidupan Masyarakat}

Secara historis, instrumen adat kalosara merupakan landasan dasar dari keseluruhan sistem sosial budaya masyarakat Tolaki termasuk pendidikan, kaidah-kaidah hidup bermasyarakat, sistem normanorma, sistem hukum dan aturan-aturan lainnya. Dalam kehidupan sosial budaya masyarakat Tolaki sehari-hari secara umum baik merupakan rakyat biasa, sebagai seorang tokoh formal maupun nonformal, nilai-nilai kepemimpinan yang terkandung dalam instrumen adat kalo berintikan persatuan dan kesatuan, keserasian dan keharmonisan, keamanan dan kedamaian. Lembaga kalosara juga menjadi landasan kultural bagi setiap individu dalam menciptakan suasana kehidupan bersama yang aman damai serta dalam menegakkan aturan baik berupa hukum adat maupun hukum negara (Tawulo dkk, 1991; Tarimana, 1993; Su'ud, 1992; Tondrang, 2000). Karena itu bagi Masyarakat Tolaki menghargai, mengkeramatkan dan mensucikan kalo berarti mentaati ajaran-ajaran nenek moyang mereka. Apabila mereka berbuat sebaliknya, diyakini akan mendatangkan bala atau durhaka (Tarimana, 1993; Su’ud, 1992).

Kalosara secara antropologis merupakan unsur budaya yang merupakan suatu pusat dalam kebudar... T-1 1.: .1.................. ak akt ii-

ha1 ) eh

Lin cial

inte $\mathrm{tu}$ -

da!

mas t. ga

do 1 if $\mathrm{n}$ be1 


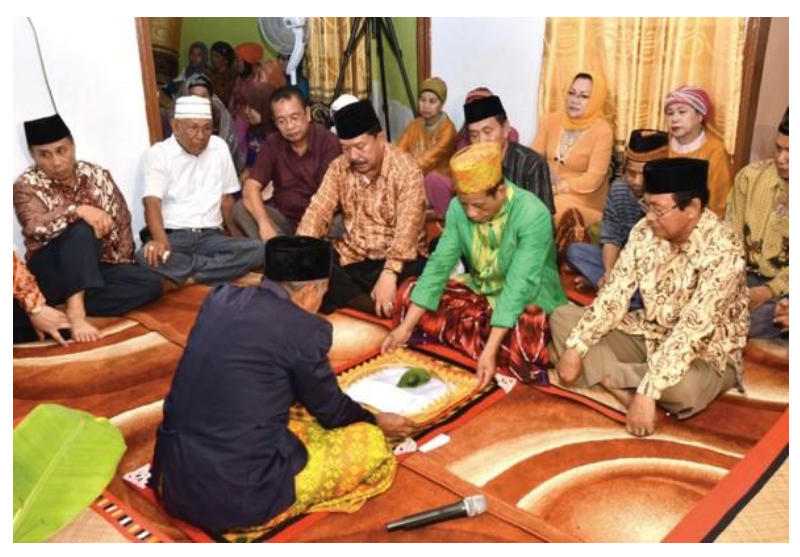

Gambar 4. Tampak Seorang Tolea dan Pabitara Sedang Melaksanakan Amanah Kedua Pelah Pihak (Keluarga Calon Mempelai Laki-laki dan Keluarga Calon Mempelai Perempuan)

Etnopedagogi yang didasarkan nilai-nilai tradisi Jawa misalnya telah diungkap oleh beberapa ahli. Nilai kepemimpinan pendidikan Jawa yang paling dikenal luas adalah konsep yang disampaikan oleh Ki Hajar Dewantara yang terdiri dari 3 aspek kepemimpinan yaitu (1) ing ngarsa sung tuladha, (2) ing madya mangun karsa, dan (3) tut wuri handayani. Konsep pendidikan ini bahkan diadopsi menjadi nilai pendidikan nasional di Indonesia (Surya, 2011). Bagi masyarakat Bugis etnopedagogi didasarkan pada nilai-nilai yang telah lebih dahulu dikembangkan oleh La Mellong yang bergelar Kajao Laliddong seorang cendekiawan (negarawan) dari Kerjaan Bone atau penasehat Raja Bone ke-6 La Uliyo memerintah 1543-1568 dan Raja Bone ke-7 La Tenri Rawe memerintah 15681584. (Ali, 1986). Semboyang tersebut berbunyi: Ri oloi napatiroang $=$ di depan memberi contoh/pentunjuk

Ri tengngai nasiraga-raga $=$ di tengah memberi semangat

Ri munri nappong lopi $=$ di belakang memberi dorongan

Semboyang ini kemudian mengilhami sikap dan perilaku dalam sistem pendidikan masyarakat Bugis/Makassar. Secara bersistem konsep pendidikan tersebut diaplikasikan dalam lembaga Pendidikan Kedinasan bernama Anreguru Ana Karung (Sejenis Sekolah Tinggi Pemerintahan Dalam Negeri) yang khusus mendidik anak bangsawan yang dipersiapkan akan menjadi calon pemimimpin di berbagai tingkatan dalam sistem pemerintahan Kerajaan Bone (Hafid, 2013a).
Dalam sistem pendidikan keluarga dan kemasyarakatan juga diimplementasikan oleh pendidik atau orang yang dituakan sebagai pendidik yang memperlihatkan keteladanan dan pemberi semangat.

Dalam masyarakat Tolaki, terdapat filsafat pendidikan yang berakar pada ungkapan Inae kosara ie pinesara; ie liasara ie pinekasara = siapa yang tahu adat akan dihormati; siapa yang melanggar adat akan dikasari. Dari filsafat ini kemudian tersimpul dalam simbol kalosara yang mengatur tata hubungan antar manusia dan lingkungannya (Tamburaka, 2004).

Dalam hubungan antar anggota masyarakat ini, terdapat unsur-unsur yang mengandung nilai filsafat tinggi. Mereka menjadikannya sebagai tongkat pegangan untuk menjalani kehidupan sehari-hari. Adapun jenis budaya hasil karya dan cipta yang mempunyai nilai sosial tinggi dan merupakan perwujudan karakter positif yang lahir dari etnopedagogi melalui media kalosara antara lain:

\section{Kohanu}

Kohanu, sering juga disebut dengan budaya malu. Kohanu, merupakan sistem pertahanan moral bagi diri sendiri, misalnya ada orang yang dikatakan malas bekerja, maka selanjutnya mereka menerapkan budaya kohanu ini dengan cara lebih tekun dan rajin dalam bekerja, sehingga sebutan sebagai pemalas akan hilang dari dirinya, berganti dengan sebutan pekerja keras yang rajin dan tekun. Secara tidak langsung budaya ini mengajak setiap orang untuk selalu memaksimalkan tenaga maupun pikiran yang dimilikinya untuk memajukan dia sendiri atau anggota kelompok yang lain.

\section{Merau}

Merau, adalah budaya yang mengajak orang untuk selalu mengedepankan sikap sopan dan santun dalam pergaulan, serta mau memberikan rasa hormat bagi semua anggota masyarakat Tolaki maupun orang lain.

\section{Samaturu}

Samaturu, merupakan salah satu budaya yang mengutamakan hidup untuk selalu menjalin persatuan, suka menolong orang lain yang sedang membutuhkan pertolongan dengan senang hati. Ini juga merupakan wujud dari gotong royong yang menjadi pandangan hidup utama dari masyarakat Tolaki. 


\section{Taa Ehe Tinua-Tuay}

Taa ehe tinua-tuay, merupakan ajakan untuk selalu merasa bangga karena menjadi bagian dari masyarakat Masyarakat Tolaki. Sesungguhnya budaya ini menjadi bagian dari Kohanu. Namun karena adanya suatu perbedaan yang bersifat mengutamakan kemandirian, maka budaya yang satu ini selanjutnya dipisah menjadi budaya sendiri.

\section{O'Sapa}

Istilah $O$ 'sapa ialah semacam aturan-aturan klasik yang mengatur hubungan hukum antara manusia dengan hewan. Hubungan-hubungan itu timbul manakala manusia melakukan pemburuan (berburu) terhadap binatang liar seperti kerbau, rusa dan anoa, dengan menggunakan tombak, menggunakan anjing, perangkap, dan alat-alat penangkap lainnya, Aturan-aturan $O$ 's $a \neg p a$ itu berwujud ketaatan/kepatuhan setiap orang/pemburu mengambil bagian dari jerih payah yang tidak menyalahi ketentuan "O'sapa.," misalnya: Bila binatang buruan itu mati berkat bantuan peralatan tombak dan anjing, maka bagian tertentu dari daging kerbau atau rusa itu, harus diberikan kepada anjing (pemilik anjing) dan tombak (yang menombak pertama) diluar dari bagian tertentu yang biasa diberikan/diambil/dikuasai si pemburu (3/4 bagian) dan bagian penguasa wilayah untuk daging dan tulang-tulang tertentu. Bila binatang, tersebut adalah binatang liar, tetapi bekas binatang peliharaan, maka aturan pembagiannya telah tertentu pula bagi pemburunya, untuk anjing, untuk tombak dan untuk penguasa wilayah/pu'utobu atau kepala kampung.

Aturan-aturan pembagian itulah disebut $O$ 'sapa, yang menurut kaidah hidup bermasyarakat harus dipatuhi oleh semua Masyarakat Tolaki termasuk Penguasa/Raja. Bila aturan hukumnya tidak dijalankan, maka da $\neg$ pat menimbulkan dampak negatif terhadap kehidupan masyarakat dan negeri.

\section{O'liwi}

O'liwi ialah seperangkat pesan wasiat, nasihat dan petunjuk hidup yang ditinggalkan/diwasiatkan untuk diikuti oleh anak cucu /generasi berikut dari para leluhur, secara turun temurun terutama dalam hal ini dapat disamakan dengan Yurisprudensi artinya putusan Hakim tertinggi yang telah berlaku tetap yang dapat dicontoh oleh Hakim-hakim berikutnya dalam perkara yang sama maupun selainnya (Hafid, 2012b).
Kedelapan jenis aturan tersebut, berawal dari kalosara dan juga berakhir pada kalosara. Kondisi tersebut terjadi karena kalosara merupakan norma tertinggi dalam kehidupan social, sehingga berfungsi sebagai landasan filosofis dan dapat diaplikasikan dalam kehidupan sehari-hari. Dengan demikian Implementasi kalosara dapat ditelaah secara empiris, misalnya sejauhmana kalosara dijadikan nmedia untuk mentransformasikan pengetahuan, nilai, dan keterampilan dari seorang kepada orang lain baik secara individual maupun kelompok. Secara cultural semua aktivitas social harus disandarkan pada kalosara, sehingga tidak satu orangpun anggota masyarakat Tolaki yang tidak pernah menyaksikan alat kalosara, termasuk menjadi partsipan dalam kegiatan implementasi pemanfaatan kalosara.

Upaya kristalisasi nilai-nilai tersebut, maka pemerintah Kerajaan Konawe dahulu kala telah mendirikan suatu lembaga pendidikan pengkaderan calon pemimpin yang bernama Inae Sinumo yang berkedudukan di Abuki mirip dengan fungsi Sekolah Tinggi Pemerintahan Dalam Negeri. Melalui lembaga Inae Sinumo ini diharapkan internalisasi nilai-nilai kalosara dapat dipertahankan dan dikembangkan oleh seluruh lapisan masyarakat, yang senantiasa didukung dan dipelopori oleh pemimpin yang benar-benar memahami dan berkomitmen mengembangkan kalosara dalam kehidupan masyarakat Tolaki.

Kalosara difungsikan baik sebagai penyebab suatu kegiatan/acara, maupun sebagai akibat. Contoh sebagai penyebab: Dalam suatu rangkaian pernikahan, kalosara wajib diadakan sebagai instrumen utama adat dan sekiranya kalosara tidak ada, maka acara tidak bisa dilaksanakan. Contoh sebagai akibat: jika terdapat dua orang yang berselisih paham, maka untuk mendamaikan harus diadakan kalosara. Akhirnya, apapun aktivitas masyarakat Tolaki, maka kalosara harus ada, sehingga semua aktivitas seseorang dan kelompok orang harus selalu bersandar pada kalosara.

\section{SIMPULAN}

Fungsi kalosara dalam masyarakat Tolaki merupakan sumber dari segala adat-istiadat dapat digolongkan ke dalam 5 cabang, yaitu: (1) sara wonua, yaitu adat pokok dalam pemerintahan; (2) sara mbedulu, 
yaitu adat pokok dalam hubungan kekeluargaan dan persatuan pada umumnya; (3) sara mbe'ombu, yaitu adat pokok dalam aktivitas agama dan kepercayaan; (4) sara mandarahia, yaitu adat pokok dalam pekerjaan yang berhubungan dengan keahlian dan keterampilan; dan (5) sara monda'u, mombopaho, mombakani, melambu, dumahu, meoti-oti, yaitu adat pokok dalam berladang, berkebun, beternak, berburu, dan menangkap ikan. Ada empat fungsi kalosara, yaitu: (1) ide, (2) fokus dan pengintegrasian unsur-unsur kebudyaan, (3) pedoman hidup, serta (4) pemersatu.

Fungsi kalosara sebagai media etnopedagogik merupakan praktek pendidikan berbasis kearifan lokal dalam berbagai ranah seperti pengobatan, seni bela diri, lingkungan hidup, pertanian, ekonomi, pemerintahan, dan sistem penanggalan. Melalui media kalosara, maka pengetahuan, nilai, dan keterampilan berbasis sosial budaya Tolaki dapat tumbuh dan berkembang di tengah-tengah masyarakat sebagai pengembangan karakter positif. Berbagai pengetahuan, nilai, dan keterampilan dapat ditransfer melalui etnopedagogi dengan memanfaatkan kalosara, yaitu: Kohanu, budaya malu, merau, budaya yang mengajak orang untuk selalu mengedepankan sikap sopan dan santun dalam pergaulan, samaturu, budaya yang mengutamakan hidup untuk selalu menjalin persatuan, suka menolong orang lain, taa ehe tinua-tuay, merupakan ajakan untuk selalu merasa bangga karena menjadi bagian dari masyarakat Tolaki, o'sapa, ketaatan/kepatuhan setiap orang/pemburu mengambil bagian dari jerih payah yang tidak menyalahi ketentuan. O'wua aturan/ketentuan hukum tata-cara bercocok tanam, merambah hutan, menanam padi, o'lawi aturan dasar yang mengatur tentang tata cara pemberian upah, imbalan jasa, pembagian kerja. O'liwi, pesan/wasiat, nasihat dan petunjuk hidup yang ditinggalkan/diwasiatkan untuk diikuti oleh anak cucu.

Akhirnya, masyarakat Tolaki perlu memelihara peran pabitara (juru bicara adat) yang selalu hadir menjadi mediasi dalam berbagai permasalahan masyarakat dengan memanfaatkan instrumen kalosara. Demikian pula peran Tolea yang selalu hadir dalam urusan peminangan, pernikahan, dan perceraian juga memanfaatakan instrument kalosara. Kedua tokoh masyarakat tersebut menjadi pendidik dalam sistem etnopedagogi untuk berbagai pengetahuan, nilai, dan keterampilan yang dibutuhkan terutama pengembangan karakter bangsa dengan memanfaatkan kalosara sebagai media utama.

\section{DAFTAR RUJUKAN}

Ali, A. Muh. (1986). Bone Selayang Pandang. Damai, Watampone.

Alwasilah, A.C. (2008). Tujuh Ayat Etnopedagogi. Artikel dalam Pikiran Rakyat Bandung, 23 Januari 2008.

Arta, Arwan Tuti. (2009). Laku Spiritual Sultan: Langkah Raja Jawa Menuju Istana. Galangpress, Yogyakarta.

Khamaganova, Erjen. (21-23 September 2005). Traditional Indigenous Knowledge: Local View. Paper presented in in International Workshop on Traditional Knowledge. Panama City.

Hafid, Anwar; Ahiri, Jafar; dan Haq, Pendais. (2012a). Konsep Dasar Ilmu Pendidikan. Alfabeta, Bandung.

Hafid, Anwar. (27-29 November 2012b). Kalosara Sebagai Instrumen Utama Dalam Kehidupan Sosial Budaya Masyarakat Tolaki di Sulawesi Tenggara. Makalah Disajikan dalam Prakongres Kebudayaan Indonesia di Jakarta.

Idaman. (2012). Kalosara sebagai Medium Resolusi Konflik Pertanahan pada Masyarakat Tolaki di Kabupaten Konawe Sulawesi Tenggara. http://idamanalwi.multiply.com/journal. Akses, 5 Oktober 2012

Koentjaraningrat. (1981). Kebudayaan Mentalitas dan Pembangunan. Gramedia, Jakarta.

La Taena, dkk. (2016). "Tradisi Khabanti Kantola sebagai Model Pendidikan Karakter Terintegrasi Kurikulum Lokal dalam Pendidikan Seni Budaya di Sekolah Menengah Kabupaten Muna".Dalam Mudra Jurnal Seni dan Budaya. 31/01. Pusat Penerbitan Institut Seni Indonesia Denpasar: 
Linton, R. (1984). The Study of Man (Antropologi Suatu Penyelidikan Manusia). Diterjemahkan oleh Firmansyah. Jemmars, Bandung.

MacNeill, N. et al (2003). Beyond Instructional Leadership: Towards Pedagogic Leadership. Australian Association for Research in Education. Auckland.

Peursen, C.A. Van. (1988). Strategi Kebudayaan. Kanisius. Yogyakarta.

Suardika, I Ketut dan Hafid, Anwar. (2016). "Peranan Tradisi Lisan Iko-iko Berbasis Sastra Melayu dalam Penguatan Komunitas Etnis Bajo". Dalam Mudra: Jurnal Seni dan Budaya. 31/01. Pusat Penerbitan Institut Seni Indonesia Denpasar.

Surya, Priadi. (2011). Kepemimpinan Etnopedagogi di Sekolah. Dalam Majalah Ilmiah Dinamika UNY Bulan Mei 2011.

Su'ud, Muslimin, (1986). Asas-Asas Hukum Adat Pertanahan Masyarakat Tolaki. Kendari: Balai Penelitian Universitas Haluoleo.

Su'ud, Muslimin, (1992). Aneka Ragam Kebudayaan Tolaki. Kendari: Balai Penelitin Universitas Haluoleo.

Su'ud, Muslimin, (2012). Kompilasi Hukum Adat Perkawinan di Sulawesi Tenggara. HISPISI Cabang Sultra. Kendari.
Tamburaka, Rustam, E. dkk. (2004). Sejarah Sulawesi Tenggara dan 40 Tahun Sultra Membangun. Unhalu Press. Kendari.

Tarimana, Abdurrauf. (1995). Kebudayaan Tolaki. Balai Pustaka. Jakarta.

Tawulo, Asrul, (1991). Mondau Sebagai Sistem Perladangan Masyarakat Tolaki dan Pengaruhnya Terhadap Kelesatarian Sumber Daya Hutan di Kabupaten Kendari. Kendari: Balai penelitian Universitas Haluoleo.

Tilaar, H. A. R. (1993). Pengembangan Sumber Daya Manusia yang Berbudaya dalam Pembangunan Jangka Panjang Kedua. LPMP-IKIP Jakarta.

(1999). Pendidikan, Kebudayaan, dan Masyarakat Madani Indonesia. Remaja Rosdakarya, Bandung.

Tondrang, Azis, (3 Juni 2000). Peranan Kalosara dalam Pembentukan Karakter Masyarakat Tolaki. Unaaha: Makalah dalam Rangka Musyawarah Adat I Suku Bangsa Tolaki.

\section{Narasumber}

Misran Safar (47 tahun) PNS, Peneliti Budaya Tolaki, Tinggal di Kota Kendari.

Muslimin Su'ud (75 tahun) Praktisi Adat dan Tokoh Masyarakat, Pensiunan PNS, Tinggal di Ranomeeto Kabupaten Konawe Selatan. 